\title{
Political Party and Municipal Councils' Strategies in Empowering Women Ward Councillors in South Africa
}

\author{
Brian K. Majola \\ Faculty of Management and Law, \\ School of Economics and Management, \\ University of Limpopo, Polokwane, \\ South Africa
}

DOI: https://doi.org/10.36941/ajis-2022-0050

\section{Abstract}

In South Africa, women and Black people became councillors after the first non-racial democratic local government elections between 1995 and 1996. One can be elected as councillor irrespective of race, gender or level of education. The country's electoral system allows women's presence in politics to largely depend on political parties. However, the number of women ward councillors has been unstable as some women leave the office after one term. It is political parties and municipal councils that can shape and ensure women's stay in politics by empowering them. The paper aims to determine whether there are any strategies employed by selected municipal councils to empower women ward councillors. It explores whether there is any training provided by the municipal council to sensitise both council and community members on gender issues. The paper strives to explore whether political parties are grooming enough women to participate in politics and contest in elections. The study is exploratory and qualitative in nature. It focuses on Ward and PR councillors, from six local municipalities in the KwaZulu-Natal and Eastern Cape Provinces who were interviewed using an interview guide. The findings of the study were analyzed using content analysis and themes were induced from the interview data. The results indicated that there were no strategies adopted by the municipal councils to empower women councillors. There was no training to sensitise both council and community members about gender issues and women are not groomed by their political parties to be ready to contest the elections.

Keywords: Women ward councillors, women empowerment, political party recruitment, gender equality and elections, local government strategies

\section{Introduction}

Women's empowerment in all spheres of life has been a challenge in both developed and developing countries. Women face discrimination from within their political parties, communities, council members and families when they contest for elections. Nonetheless, the United Nations (UN) has been instrumental in persuading member states to remove all discriminatory practices and empower women with its conventions; recommendations and conferences. For example, the 2030 Agenda for Sustainable Development, with 17 Sustainable Development Goals (SDG), SDG 5 which concerns gender equality and women empowerment, encourages women's representation in political parties and their training to be effective leaders. Furthermore, women empowerment theories such as the 
capability approach and the human development approach have been introduced to address gender inequalities at national, organisational and community levels. At continental level, the African Union's (AU) African Charter on Human and People's Rights (adopted in 1981), Article 18 aims to eliminate discrimination against women and ensure the protection of the rights of women as stipulated in international declarations and conventions (AU, 2021a). In 2003, the AU adopted a Protocol to the African Charter on Human and People's Rights of Women in Africa, also known as the 'Maputo Protocol'. Recently, the AU Strategy for Gender Equality and Women's Empowerment (20182028) (GEWE Strategy) was introduced to member states. The GEWE Strategy aims to mitigate the major constraints hindering gender equality and women's empowerment, to enable the participation of women and girls in economic activities, political affairs and social activities (AU, 2021b). The Southern Africa Development Community (SADC) Protocol on Gender and Development of 2008, aims to empower women, eliminate discrimination and to achieve gender equality and equity within the region (SADC. Int, 2021). The Framework for Achieving Gender Parity in Political and DecisionMaking Positions provided strategies and guidelines to ensure that at least 50\% of all decisionmaking positions at all levels would be held by women by 2030 (SADC, 2021). Gender mainstreaming has become a priority for the majority of democratic countries as they have reviewed their national policies to bring women into the political sphere and ensured their equal representation in all structures where decisions that affect them are taken. However, political parties are women's direct vehicle to access elected office, and municipal councils should ensure their development together with other relevant institutions. Municipal councils can empower women by training and sensitising council and community members on gender equality issues. Furthermore, community women would be made aware that they do not need political parties to be elected as ward councillors as they could contest the elections as independent candidates. In South Africa, community members still have a challenge of trusting women with positions due to lack of understanding the importance of gender equality in politics. It must be noted that women including White, Blacks, Coloureds, Indians and Chinese people started working as municipal councillors after the first non-racial democratic local government elections from November 1995.

According to the Constitution Act of 1996 (South Africa, 1996) and the Municipal Systems Act, Act 32 of 2000 (South Africa, 2000), municipal councils make decisions concerning the exercise of all the powers of the municipality. One can be elected as a councillor irrespective of race, gender or level of education (Majola, 2021). The country's electoral system allows for the presence of women in politics and to a large extent, their progress to certain roles depends on political parties. Alternatively, women as individuals can contest municipal elections as independent ward candidates. An independent woman ward candidate must be nominated by any resident from that ward, provided she meets the requirements. Once independent women candidates have been elected, the municipal council should have strategies and programmes to empower them. The Speaker, appointed in terms section 37 of the Municipal Structures Act, Act 117 of 1998 (South Africa, 1998) has a duty to provide support, assistance and necessary training for councillors (Majola, 2019). However, women have not yet fully utilised the option of contesting elections as independent candidates. As a result, the number of women ward councillors has been inconsistent as some women leave office after one term. It is political parties and municipal councils that can shape and ensure women stay in politics by empowering them. Firstly, the study aims to determine whether training is provided by the municipal council to sensitise both council and community members on gender issues. Secondly, it explores whether strategies are employed by selected municipal councils to empower women ward councillors. Lastly, the study strives to explore whether political parties are grooming women to participate in politics and contest in elections at the local government level.

\section{Research Methodology}

The research design employed in this study is exploratory and qualitative. The focus was on EThekwini Metropolitan Municipality and four local municipalities under UMgungundlovu District 
in KwaZulu-Natal as well as uMzimvubu Local Municipality in the Eastern Cape Province (EC). There were twenty-three (23) women ward councillors; thirty-seven (37) male ward councillors, thirty (30) women PR councillors and fourteen (14) male PR councillors that participated in the study. In-depth semi-structured interviews were adopted. Face-to-face and telephone interviews were conducted as some respondents were in the EC. The secondary data included documents such as annual municipal reports, national policies and local government prescripts and other publications. Content analysis was used and themes were induced from the interview data. Data was presented in the form of tables and percentages. The gatekeeper's letter was obtained from targeted municipalities and ethical clearance from the University of KwaZulu-Natal was granted. The issue of confidentiality was communicated to all respondents.

\section{Empowerment Theories and Legislative Framework on Gender and Political Party's Strategies}

This section focuses on women empowerment theories, international agencies' role, municipal related prescripts and gender equality strategies for political parties in women ward councillor's empowerment at local government level.

\section{1}

\section{Women empowerment theories}

There is no single definition of empowerment. Based on Freire's (1970) argument on the pedagogy of the oppressed in terms of empowerment, many definitions can be highlighted. For example, Kabeer (2002) defines empowerment as the process by which those who have been denied the ability to make strategic life choices acquire such an ability. Applied to gender issues, the discussion of empowerment brings women into the political sphere, both private and public (Kabeer, 2002; Tandon, 2016). In this context, empowerment is a process to change the distribution of power between men and women, both in interpersonal relations and in institutions throughout society (Kabeer, 2002). When there is achievement, it ranges from improved 'well-being' to achieving equal representation of women in politics (Huis, Hansen, Otten and Lensink, 2017). The empowerment theory allows for the differentiated perspective in addressing the unequal relations between the genders (Hall, 2010; van der Waldt, Fourie, van Dijk, Chitiga-Mabugu, and Jordaan, 2019).

At the national level, South Africa has established structures for gender equality and women empowerment. These include the Ministry of Women; national gender machinery; Offices on the Status of Women; Gender Focal Points and Women's Forums; Parliamentary Women's Group and the Women's Empowerment Committees and the Committee on the Improvement of the Quality of Life of Women in Provincial Legislatures (van der Waldt, et al. 2019).

\subsection{Legislative Framework on Gender at the local level}

When one tries to address issues of women empowerment, there are various United Nations (UN) conventions, recommendations and conferences from the Universal Declaration of Human Rights, Article 21 (1948); to the Convention on the Political Rights of Women, Article 1 (1952); Convention on the Elimination of All Forms of Discrimination against Women (CEDAW) that encourage Member States to introduce laws and policies to promote equality between women and men. The African Union (AU) African Women's Rights Protocol (2003) and The African Charter on Democracy, Elections and Governance (2012) (ACDEG) reiterate that women must be represented equally at all levels in all electoral processes. The Southern African Development Community (SADC) Protocol on Gender and Development seeks to ensure that women hold 50\% of decision-making positions in all sectors (IDEA, 2016; SADC.Int, 2021). Many Member States of SADC have codified legal provisions on women's right, but practically there are still challenges in terms of women's participation in politics. Politics is still male-dominated although the majority of the population are women. Gender issues, 
specifically at grassroots level need to be addressed as women are severely marginalised in terms of service delivery and decision-making processes. The 2030 Agenda for Sustainable Development, SDG 5 aims to promote the attainment of gender equality and empowerment of all women and girls as it advocates for their effective participation at all levels of decision-making in political and socioeconomic sectors. Two of its five strategic objectives are to strengthen women's leadership through training including young women as change agents and encourage political parties to address substantive representation in their policies and operations. The SDG 5 aim is to facilitate and promote training especially relating to women's empowerment to strengthen their technical and practical knowledge on public policy management (Coates, 2014).

Section 152 of the Constitution, Chapter 7 (South Africa, 1996) states that local government should provide a democratic and accountable government for local communities; and encourage the involvement of communities and community organisations in matters of local government. The White Paper on Local Government (1998), states that municipalities should follow steps to ensure that representatives from marginalised groups such as women and the poor stand for elections. The emphasis is on accountability at it strengthens the role of councillors for the benefit of all community groups including women. Ward councillors serve as a link between the ward community and the rest of government for proper consultation with local communities for planning and implementation of provincial and national programmes impacting on the ward. The Municipal Structures Act (South Africa, 1998) encourages political parties to have equal numbers of women and men as candidates. Section 21 of the Act states that one can be elected as a councillor irrespective of race, gender or level of education (Majola, 2021). The participatory form of democracy is evident in the Municipal Systems Act (South Africa, 2000; Majola, 2019) where a community consists not only of the structures, functions and administrators of the municipality, but also the communities, residents and ratepayers of the municipality (Cameron, 2001; Majola, 2019). These prescripts allow women to participate in politics freely just like their male counterparts.

\subsection{Gender Equality Strategies for Political Parties}

There are three types of strategies utilised by political parties in addressing gender equality. Firstly, rhetorical especially using declarations, speeches or resolutions. Secondly, positive action that promotes the use of incentives such as training, funding and the creation of gender mechanisms. Lastly, positive discrimination where quotas are used for internal structures or lists to elective offices (Lovenduski and Norris, 1993). The UNDP (2011) identified interventions for political parties concerning women empowerment. The electoral cycle approach consisted of four phases where the first one is foundation strategies for internal party organisation. Firstly, the party can adopt a statement on gender equality and quotas in its framework. Many parties are still reluctant to undertake internal reform to promote substantive gender equality between women and men (IDEA, 2016). Secondly, the political party can have strategies in the pre-electoral period, where they deal with the recruitment and nomination of candidates. Thirdly, strategies in the electoral period, where women candidates can learn campaigning techniques that can be adopted. Lastly, political parties can have strategies in the post-electoral period, where they can sensitise party members about gender equality and capacitate elected women.

Women in South Africa are more organised at local level and that is where women ward councillors should gain more support. Political parties should involve all the stakeholders including civil society, churches, women's groups and traditional leadership to influence their policy documents. All the policies can be reviewed to incorporate gender equality issues and also change rules and regulations of the party. Once elected, women ward councillors can receive support from these key stakeholders. 


\section{Political Parties' Role in Women's Election and Empowerment}

\subsection{Political parties' performance and women's election at the local level}

Political parties are key stakeholders in an election (IEC, 2016). Independent Candidates can also stand to be elected as a councillor after being nominated by any resident. Women must first become candidates to be elected (Dolan, 2010; Funk, Hinojosa and Piscopo, 2017). However, men are mostly in decision making positions which affect the selection and nomination process within political parties. The reason more women are not winning elections is that few women choose to run (Wilson, 2017) and they generally wait to be asked before running for office (Beck, 2016). In addition, the society's patriarchal mindset cannot be ruled out. Women face hurdles even in the candidate selection phase, including gender stereotypes that deem them less competitive and less qualified (Dolan, 2010). If their party win insufficient votes in an election, women are put on the list in the order that they are not elected (Mkhize, 2015).

The Municipal Structures Act (South Africa, 1998) encourages political parties to have equal numbers of women and men as candidates. Cheeseman and Dodsworth (2019) questioned whether quotas empower women or serve as a means of political control. In South Africa, local government elections are conducted in terms of a mixed electoral system that combines closed proportional representation (PR) party lists with directly elected ward representatives (IEC, 2016). In the 2016 local elections, the ANC received majority votes followed by the Democratic Alliance (DA), although the total share of votes decreased from $62.93 \%$ in 2011 to $53.91 \%$. The overall share of the vote for the DA increased from $24.1 \%$ in 2011 to $26.90 \%$, gaining three metropolitan municipalities from the ANC. The Inkatha Freedom Party (IFP) after gaining control of 11 municipalities and UDM became the second opposition parties in the EC and KwaZulu-Natal (KZN) municipalities. The Economic Freedom Fighters (EFF) after its formations and as a splinter from the ANC in July 2013, emerged as the significant third political party by gaining $8.19 \%$ total share of the vote.

\subsection{Recruitment of Women at Local Government Level}

Political parties are key to women's participation in politics, as political parties recruit and select candidates for elections and that determines the country's policy agenda (UNDP, 2011). Political parties often do little to prepare women for office and provide little support for them once elected (Sales, 1997). Research shows that the women's section in political parties can play multiple roles: attracting women voters and women members; encouraging women to stand for election to party leadership positions and legislatures; acting as a support network for women politicians and creating women's policy (Freeman, 2000; in Curtin, 2008). For the reformation in South Africa, political parties should work with stakeholders such as civil society, government, and institutions of higher learning. They should adopt a statement on gender equality in the party's constitution and mainstream gender in policy development and implementation. The women's section should participate at strategic level with funding and adequate resources to ensure equal representation in all structures. Furthermore, political parties should involve all stakeholders in the political education of community members. Parties would then have sufficient women on their lists for local elections.

\section{The Role of a Municipality and other Stakeholders on Women Empowerment}

The municipality plays a key role in the process of women empowerment as the municipal council and the Speaker host all the councillors including PR and independent councillors. Other key stakeholders responsible for training and development of local government officials such as SALGA and the Department of CoGTA are discussed in this section with the aim of understanding progress made towards women ward councillors' empowerment. 


\subsection{Municipal council and the speaker}

In terms of Schedule 5 of the Constitution (South Africa, 1996), the council is responsible for the roads, public transport, street trading, water and electricity. A Speaker is the chairperson of a municipal council in terms of section 36 of the Municipal Structures Act (South Africa, 1998). According to section 37, the Speaker should preside at council meetings; ensure compliance in the council and its meetings with the Code of Conduct, and ensure the necessary training for councillors, provide support and assistance (Majola, 2019). The Speaker plays a role in monitoring the degree to which councillors are open and accountable towards the community (SALGA, 2011; Majola, 2019). When there are complaints or conflict between councillors or a councillor and community members, the speaker will investigate and refer the matter to the Rules, Ethics and Integrity Committee. If not resolved, the executive council or mayoral committee will refer the matter to the full council for a decision. If the councillor is found guilty, the Act allows the councillors to write to the Member of the Executive Council (MEC). Hence, it is crucial to empower and train ward councillors to execute their duties effectively and diligently.

Hicks (2011) maintains that there are few programmes and budget for gender equality awareness-raising at the municipal level, while some districts report dysfunctional gender structures. For municipal council training, South African Local Government Association (SALGA) normally issue a circular indicating the programme for officials to attend. The Skills Development Section of the municipality then arranges logistical matters. An invitation is sent to all councillors through the Office of the Speaker, who makes the announcement during council meetings. It must be noted that municipal councillors sit in different portfolio committees or any training for community members.

In terms of section 16 of the Remuneration of Public Office Bearers Act No. 20 of 1998 (South Africa, 1998), municipalities have to budget for development and implementation of capacity building programmes for its councillors. Councillors may attend short courses in terms of the training, education and development policy and skills development policy of the municipality. According to section 16, councillors may be trained by national and provincial departments; private agencies; SETA's and municipalities and organised local government. Capacity-building should be based on the skills development and personal development plans of each councillor. With the personal development plan, councillors may indicate areas for development and the municipal council will assist with organising relevant training programmes. The Remuneration Act (South Africa, 1998) also states that the needs of councillor's statutory obligations and affordability by the municipality must be taken into consideration. Councillors are also trained by SALGA on the various criteria for assessment and issues as councillors are representing their communities irrespective of their political affiliation.

\section{2}

SALGA and councillor's empowerment

The SALGA's existence is anchored on section 163 of the Constitution (South Africa, 1996) and the Organised Local Government Act (South Africa, 1997). The White Paper on Local Government (1998) states that SALGA is the only body responsible for the training of local government officials. The objectives in terms of the Constitution includes enhancing the role and status of municipalities; and ensuring the full participation of women in organised local government.

In 2018, SALGA in partnership with WITS School of Governance graduated 105 officials from all provinces on Leadership in Municipal Governance Programme (Mbambato, 2018). However, Sebola (2014) argued that the use of higher education institutions for training and the challenging realities of the typical councillors makes it difficult to determine and confirm SALGA capacity in dealing with training for development in South African municipalities. He pointed out that the quality of training programmes provided by universities and NGO's may not be of the same quality as expected by SALGA, due to standards of training and cultural approaches. Miller (2013) pointed out that training programmes offered by SALGA were not compulsory for officials and were therefore not sufficiently 
utilised (quoting Mr Nombembe former Auditor-General).

\subsection{The Department of CoGTA and ward councillor training}

The department has been instrumental in the development and implementation of policies for municipalities as well as capacity building. According to the former KZN MEC Nomusa Dube-Ncube, CoGTA budgeted R1.6bn for period 2018/19 for a capacity-building where out of 1.846 councillors, 234 had some schooling but no matric, four did not have schooling, while 322 had only matric as the highest qualification (Mthethwa, 2018). The Department of CoGTA offers a women councillor a training programme, which is aligned to the National Certificate: Local Government Councillor Practice (van der Waldt, et al. 2019). The study conducted in South Africa by van der Waldt, et al. (2019), revealed that $56.12 \%$ of councillors and $74.13 \%$ of officials indicated that they regularly receive training to improve their administrative and managerial functioning.

\section{The Role of Civil Society Structures on Women Empowerment}

Civil society as social partners of the State have been involved in the development of legislative and policy framework in different parts of the world. In South Africa, civil society representing millions of poor people and movements such as the United Democratic Party (UDF) in the 1980s, revolted to force the apartheid government to provide basic services such as housing electricity, water and roads in the townships. Women in the civic movement were at the forefront in the struggle against high rent and service charges (Beall, 2004). Sales (1997) affirms that women are used by political parties because of their strong links with local communities which can be turned into electoral support. With regards to political movements, the ANC is the only political party in South Africa if not in Africa that has launched its political school called the OR Tambo School of Leadership in April 2019.

\section{Findings}

The results from primary and secondary data were analysed and presented using tables which list the themes and the frequency of the responses (Majola, 2021). To identify strategies provided by political parties and municipal councils in empowering women ward councillors, three questions were asked. In this study, not only women councillors responded to questions but all the respondents shared their experiences.

\section{1 $\quad$ Training on gender issues}

The first question probed whether training has been provided at local government level to sensitise the municipal council and/or community members about gender issues. Table $\mathbf{1}$ shows the themes and frequency of responses.

Table 1: Training of Council/Community Members

\begin{tabular}{|l|c|}
\hline Themes & Frequency of Responses \\
\hline No training provided & 63 \\
\hline Have attended a few courses & 41 \\
\hline
\end{tabular}

The majority of respondents $61 \%(n=63)$ indicated that no training has been provided to sensitise council and/or community members. Respondent 102 said that "councillors are chosen but not trained". It implies that organisations such as SALGA and CoGTA need to focus on gender issues. Section 47 of the Municipal Structures Act (South Africa, 1998) states that the Speaker should ensure the necessary training for councillors, provide support and assistance. Also, the Remuneration Act 
(South Africa, 1998) allows for the municipality to organise short courses for councillors which can be provided by government departments, private agencies in terms of the policy and skills development plan of the municipality. It must be noted that some respondents, mostly males, mentioned that they would never attend gender training because gender was not more important than community issues.

Thirty-nine percent $(n=41)$ of the respondents mentioned that they have attended a few courses that sensitised them on gender issues. Respondent 25 explained that the MEC provided "training for women councillors regarding women's confidence, conduct in meetings, responding to questions, and the dress code". This response is in line with Hicks (2011) who expressed that there are few programmes and budgets for gender equality awareness-raising at the municipal level, but gender structures are dysfunctional. The lack of municipal budget for training and development in terms of section 16 of the Remuneration Act (20 of 1998), is proof that no skills development and personal development plans are developed for councillors.

\subsection{Strategies to empower women}

Respondents were asked whether or not there are strategies in place to empower women at the local government level (see Table 2).

Table 2: Strategies to empower women

\begin{tabular}{|l|c|}
\hline Themes & Frequency of Responses \\
\hline No strategies to empower women & $\mathbf{4 4}$ \\
\hline Strategies introduced but never materialised & $\mathbf{1 8}$ \\
\hline Civil society has strategies for women empowerment & $\mathbf{1 3}$ \\
\hline Responsibility of political parties & 6 \\
\hline Yes, there are strategies & $\mathbf{2 1}$ \\
\hline Do not know & $\mathbf{2}$ \\
\hline
\end{tabular}

The majority of the respondents at $42 \%(n=44)$ reported that there were no strategies. Respondent 32 mentioned that "nothing from the municipality". The lack of strategies to empower women at local government level point to the deviation from the African Union's Women's Decade 2010-2020 which aimed at empowering women through a top-down and bottom-up approach that is inclusive of grassroots participation (Kamau, 2011). This happened even though other international organisations such as the UN and SADC introduced strategies and policies to empower women and promote equality. Furthermore, South Africa has established national structures for gender equality and women empowerment (van der Walt et al, 2019). However, clear strategies to empower women ward councillors at local government level are absent.

Only $20 \%(n=21)$ indicated that there are strategies at local government level to empower women. Respondent 26 expressed, "I managed to pass Grade 12 and attended workshops and training." From the responses, one can notice that some councillors attended courses organised by CoGTA. This is in line with Mthethwa (2018) who indicated that the KZN CoGTA budgeted 1.6 billion for the period 2018/19 for capacity building of councillors. However, it is not clear whether gender issues are addressed in these formal qualifications.

Some respondents stated that strategies were introduced, but unfortunately these did not materialise $(\mathrm{n}=18)$ at $17 \%$. Respondent 8 maintained that "strategies are there but not taken seriously...not spread across as rural women are not empowered". Councillors may be invited to planned training through the Speakers office or municipal manager, corporate services and the skills development facilitators. However, not all councillors attend as it is not compulsory and therefore not sufficiently utilised (Miller, 2013). Mbambato (2018) indicated that only 105 officials from all provinces graduated at WITS. This number is not adequate considering the number of councillors in South Africa. Hence, Sebola (2014) argued that it is difficult for SALGA to deal with the challenging 
realities of the typical councillors when they work in partnership with institutions of higher education.

Only $13 \%$ of the respondents $(\mathrm{n}=13$ ) reported that civil society had strategies for women empowerment. Respondent 98 claimed that "NGOs have trained people like myself...they have good programmes for women". The responses support Beall (2004) position that women in civil movements were at the forefront in the struggle against high rent during apartheid years. Most of the women who responded positively to this question became politically active during the 1980 and early 1990 . However, the empowerment of women by civil society declined after 1994 as most women activists moved from local to national level.

Only $2 \%(n=2)$ of the male respondents reported that they do not know whether there were any strategies to empower women at local government level as they had no idea what was discussed in women-only meetings. Six respondents $(6 \%)$ stated that it is the responsibility of political parties to empower women. Respondent 65 maintained that, "political parties are not doing much...it is still male-dominated". This is not in line with the UNDP (2011) which suggested that for women empowerment, political parties must adopt strategies at pre-electoral, electoral, and post-electoral periods where political parties can sensitise party members about gender equality and capacitate women. There are women empowerment policies and strategies at the national level in South Africa which focuses on gender equality and representation in all structures. However, from the findings of the study, it is clear that there is a lack of empowerment strategies at the meso/organisational level, especially of women ward councillors by political parties and municipal councils. As a result, it would be a struggle for communities to understand the role of women as ward councillors and support gender issues.

\subsection{Women groomed by political parties}

From the results displayed in Table 3, it can be seen that respondents $35 \%(n=36)$ felt that women are not groomed at all by political parties for representation and participation at the local government level.

Table 3: Women groomed by political parties

\begin{tabular}{|c|l|c|}
\hline Yes/No & Themes & Frequency of Responses \\
\hline No & Women are not groomed at all & 36 \\
\hline No & Women learn on the job & 26 \\
\hline No & Political parties not doing enough as only quota system works & 26 \\
\hline No & I do not know & 6 \\
\hline Yes & Women are groomed in youth sections & 10 \\
\hline
\end{tabular}

Respondent 79 added that "even in structures within the party...males do not support us because as women we are a threat to them now". Lovenduski and Norris (1993) identified strategies such as rhetorical positive action and positive discrimination where they can promote, train, fund, create gender mechanisms and use quotas for internal structures. This is in contravention with UNDP (2011) which states that political parties are key to women's participation in politics and they have to recruit and select candidates for elections. Therefore, their structures, policies, practices and values have a profound impact on women's participation in politics. If women are not groomed by political parties, it would be challenging to replace the current cohort as stated by one of the respondents.

Twenty-six respondents $(25 \%)$ indicated that women are not groomed by political parties but they learn on the job. Twenty-four percent of the respondents reported that political parties are not doing enough to groom women but rely on the quota system. Respondent 26 maintained, "We rely on the quota system; otherwise, there is nothing for women within and outside the party". This is in line with Cheeseman and Dodsworth (2019) who raised a crucial question as to whether quotas empower 
women or serve as a means of political control.

Some respondents at $10 \%(\mathrm{n}=10)$ were of the view that enough women were being groomed by political parties in the youth sections. Respondent 29 maintained "with the DA, the Young Leader's Programme is there for everyone". Although there are youth sections within political parties, the responses show that many political parties are still reluctant to undertake internal reforms to promote substantive gender equality between women and men (IDEA, 2016). The presence of women in youth sections does not guarantee that political parties are grooming more women to contest the elections. It is important to note that $5 \%(\mathrm{n}=6)$ indicated that they do not know whether or not political parties are grooming women to contest the elections at the local government level.

\section{Conclusion and Recommendations}

The study investigated whether political parties and municipal councils had strategies to empower women ward councillors in South Africa. Findings indicate that there is no training provided to sensitise council and community members on gender issues. Municipalities are supposed to budget for training and development of its councillors in terms of section 16 of the amended Remuneration Act (1998). It must be noted that several respondents attended only a few courses organised by SALGA and CoGTA which were not gender-specific. The challenge is that even when courses are organised, attendance is not compulsory for both councillors and community members. The study found that municipal councils do not have strategies to empower women councillors. Strategies to empower women at international and national levels are clearly stipulated. However, it is not only the duty of political parties to develop strategies, but also municipal councils as they host all councillors including independent women councillors. Hence, municipal councils should consult national policies and involve institutions such as SALGA, the Department of CoGTA, civil society and other stakeholders when developing their strategies. This would ensure that all women councillors are empowered irrespective of whether they affiliate with political parties or are independent councillors.

Lastly, the study revealed that women are not groomed at all by their political parties to be ready to contest the elections as they learn governance issues through trial and error. Political parties are key stakeholders in women's political empowerment and election as ward councillors. Therefore, internal reforms to promote gender equality are needed to identify young politically capable women, and money needs to be injected for training and support of women councillors once elected. The new school established by the ANC to provide political education currently does not have any course focusing on women empowerment or gender equality issues. Furthermore, the power struggle for positions makes it difficult for the party to prioritise women empowerment issues. It is clear that without the quota system, the number of women councillors in the councils would have been very low. The next municipal elections in South Africa will be held in 2021.

\section{References}

African Union. (2021a). African Charter on Human and People's Rights. Retrieved from https://au.int/en/treaties/african-charter-human-and-peoples-rights Accessed March 29, 2021.

African Union. (2021b). AU Strategy for Gender Equality and Women's Empowerment (2018-2028). Retrieved from https://au.int/en/articles/au-strategy-gender-equality-and-womens-empowerment Accessed March 29, 2021.

Beall, J. (2004). Decentralisation and Engendered Democracy: Lessons from Local Government Reform in South Africa. Working Paper No. 4 London: Crisis State Research Centre.

Beck, E. (2016). Number of Women in WV legislature at a 33-year low. Retrieved from http://web.a.ebscohost. com/ehost/delivery?sid=47f8ecc4-b9dd Accessed March 31, 2017.

Cameron, R. (2001). The Upliftment of South African Local Government. Local Government Studies, 27(3), 97-118.

Cheeseman, N., and Dodsworth, S. (2019). How to get women's voices heard in African politics? Retrieved from http://mg.co.za/author/nic-cheesman Accessed October 07, 2019. 
Coates, A. (2014). Political empowerment of women: Framework for strategic Action-Latin America and the Caribbean (2014-2017). UN Women. Panama.

Curtin, J. (2008). Women, Political Leadership and Substantive Representation: The Case of New Zealand. Parliamentary Affairs, 61(3), 490-504.

Department of Cooperative Governance and Traditional Affairs (CoGTA) (2015). Gender Policy Framework for Local Government 2015-2010. Retrieved from http://iknowpolitics.org/en/knowledge-library/report-whitepaper/south-africa-local-government-gender-policy-framework Accessed: October o6, 2019.

Dolan, K. (2010). The impact of gender-stereotyped evaluations on support for women candidates. Political Behaviour, 32(1), 69-88.

Funk, K. D., Hinojosa, M., and Piscopo, J. M. (2017). Still left behind: Gender, political parties, and Latin America's pink tide. Social Politics, 24(4), 399-423.

Hall, C. M. (2010). Women and Empowerment: Strategies for Increasing Autonomy. London: Taylor and Francis.

Hicks, J. (2011). Women's political representation and participation. Commission for Gender Equality, 1-6.

Huis, M. A., Hansen, N., Otten, S., and Lensink, R. (2017). A Three-dimensional model of women's empowerment: Implications in the field of microfinance and future directions. Frontiers in Psychology, 8(1678): 1-14.

IDEA. (2016). A framework for developing gender policies for political parties. Retrieved from https://iknowpolitics.org/sites/default/files/a-framework-for-developing-gender-policies-for-political-parties.pdf Accessed July 05, 2021.

Independent Electoral Commission. (2016). 2016 local government elections report: Report on South Africa's $5^{\text {th }}$ local government elections held on 3 August 2016. Electoral Commission, South Africa.

Independent Electoral Commission. (2021). Independent Ward Candidates. Retrieved from https://www.elections.org.za/content/Parties/Independent-Ward-Candidates/ Accessed March 26, 2021.

Kabeer, N. (2002). Resources, Agency, Achievements: Reflections on the measurement of women empowerment. Retrieved from https://onlinelibrary.wiley.com/doi/abs/10.1111/1467-7660.00125 Accessed August 16, 2021.

Kamau, M. (2011). Statement on Behalf of the African Group. New York: UN General Assembly.

Lovenduski, J. and Norris, P. (1993). Gender and Party Politics. London: Sage Publishers.

Majola, B. K. (2019). Challenges Faced by Women Ward Councillors in South Africa. Paper presented at the $4^{\text {th }}$ Annual International Conference on Public Administration and Development Alternatives (pp. 280-288), July 03-05, South Africa.

Majola, B.K. (2021). Support Extended to Women Ward Councillors by Stakeholders in South Africa. Journal of Educational and Social Research, 11(3): 78-90.

Mbambato, S. (2018). SALGA launches seminars to inspire leadership in municipalities. Retrieved from https://www.gove.za/speeches/salga-launches-seminars-inspire-leadership-municipalities Accessed September 02, 2019.

Miller, C. (2013). Insufficient Training for municipal workers: SALGA training should be compulsory. Retrieved from www.achieveonline.co.za/articles/salga-training-should-be-compulsory-6757.html Accessed September 02, 2019.

Mkhize, H. (2015). The role of women in politics, focusing the then and now. Retrieved from https://www.dtps.gov/index.php?option=com_content\&view=article\&id=535:the-role-of-women-inpolitics,-focusing-on-then-and-now Accessed September 17, 2019.

Mthethwa, B. (2018). KZN Councillors go 'back to school' to better serve the people. Retrieved from https://www.timeslive.co.za/news/south-africa/2018-11-o7-kzn-councillors-go-back-to-school-to-betterserve-the-people/ Accessed September 04, 2019.

SADC.Int. (2021). Empowerment. South African Development Community. Retrieved from https://www.sadc.int/. Accessed March 31, 2021.

Sales, R. (1997). Women Divided: Gender, Religion and Politics in Northern Ireland. London: Routledge.

Sebola, M. (2014). The Role of SALGA in Training Municipal Councillors for Development: Using the "Knowledgeable" Experts.

Tandon, T. (2016). Women Empowerment: Perspectives and views. The International Journal of Indian Psychology, 3(3): 6-12.

UNDP. (2011). Empowering women for stronger political parties: A good practices guide to promote women's political participation. United Nations Development Programme.

Van der Waldt, G., Fourie, D., van Dijk, G., Chitiga-Mabugu, M., and Jordaan, J. (2019). A Competency Framework for Women Empowerment: The Case of the Local Government Sector in South Africa. Problem and Perspectives in Management, 17 (2), 348-364.

Wilson, R. (2017). Women reach new heights in state legislatures. The Hill, February 15, 7. 